\title{
Korona-altistusten jäljittämiseen tarvitaan uusia ratkaisuja
}

Asiasanat: korona, altistuminen, jäljittäminen, RFID

\section{TAUSTAA}

Kontaktien jäljittäminen on oleellinen osa infektioiden hallintaa ja ehkäisyä. Ihmistyönä toteutettavan kontaktien jäljittämisen rinnalle tarvitaan uusia aikaa säästäviä sekä kustannustehokkaita ratkaisuja, jotka mahdollistavat myös nykyaikaisen teknologian täyden hyödyntämisen (1). Radiotaajuuksilla toimivan etätunnistusteknologian (RFID) käytöstä on jo lupaavia tuloksia (2), mutta soveltaminen terveydenhuoltoon on hidasta (1).

Koronaltistusten jäljitysprosessi on aikaa vievää sekä sen saavuttamat tulokset epävarmat, koska kontaktien kartoitus on muistinvaraista. Kun COVID -19 testi on henkilökunnan jäsenellä positiivinen, kontaktien jäljittäminen tapahtuu kyselemällä ja kartoittamalla altistuneet työntekijät yksikön esihenkilön tai vastaavan hoitajan toimesta. Kontaktien kartoitus ei ole systemaattista, se on aikaa vievää eivätkä tulokset ole luotettavia. Mikäli työyksikössä on joukkoaltistuminen ja/tai altistuminen koskee useita työyhteisön jäseniä, prosessi on huomattavan monimutkainen ja työläs. On kehitettävä uusia ratkaisuja, joiden avulla voidaan altistuneet jäljittää nopeammin ja varmemmin.

\section{KORONA-ALTISTUMINEN SAIRAALASSA}

Korona-altistumisen määritellään tapahtuneen, mikäli henkilö on ollut fyysisessä kontaktissa tai yli 15 minuuttia kestävässä kohtaamisessa altistajan kanssa alle kahden metrin etäisyydellä (24 tunnin aikana yhteenlaskettu aika, ei tarvitse olla yhtäjaksoinen). Määritelmä edellyttää lisäksi COVID-19-potilaan hoitamista ilman asianmukaista suojautumista (kirurginen suu-nenäsuojus tai hengityksen suojain FFP2/FFP3 tai kasvot peittävä visiiri) tai COVID-19-näytteiden käsittelyä. Altistuminen on tapahtunut myös, jos suojautuminen on pettänyt esimerkiksi siten, että kasvoille on päässyt hengitystie-eriteroiskeita.
Mikäli altistaja on oireinen, altistuneiksi määritellään henkilöt, jotka ovat olleet kontaktissa 48 tunnin aikana ennen altistajan oireiden alkua sekä 10 päivää tapauksen oireiden alun jälkeen. Vastaavasti, jos altistaja on oireeton, altistuneiksi määritellään henkilöt, jotka ovat olleet kontaktissa 48 tuntia ennen altistajan näytteenottoa (altistuneet siis kartoitetaan kahden päivän ajalta ennen näytteenottoa) sekä 10 päivää näytteenoton jälkeen.

\section{SELVITYS ALTISTUNEISTA TYÖNTEKIJÖISTÄ}

Kun esihenkilö saa tiedon COVID-19 positiivisesta työyhteisön jäsenestä tai mahdollisesta altistumisesta potilastyössä, hän selvittää omassa yksikössään altistuneet työntekijät sekä huomioi myös potilaat ja omaiset organisaation ohjeen mukaan. Esihenkilö huomioi myös tukipalveluiden sekä organisaation muiden yksiköiden (esimerkiksi kuvantaminen, kuntoutus, ensihoito, akuuttisijaisvälityksen varahenkilöt ja keikkatyöntekijät, osastosihteerit, osastofarmaseutit, muut erityistyöntekijät) altistuneet työntekijät sekä altistuneet lääketieteen, hoitotyön ja kuntoutuksen sekä muiden alojen opiskelijat. Esihenkilö ilmoittaa muiden työyksiköiden ja työnantajien altistuneet työntekijät heidän esihenkilölleen ja kirjaa altistuneet työntekijät tietylle lomakkeelle.

Tämän jälkeen esihenkilö on välittömästi yhteydessä altistuneisiin. Hänen on päätettävä, miten työntekijät sijoitellaan työtehtäviin mahdollisen altistumisen vuoksi - altistuneet työntekijät eivät sovellu vaikeasti immuunipuutteisten potilaiden hoitamiseen.

Esihenkilö ilmoittaa altistuneet työntekijät työterveyshuoltoon, joka on yhteydessä jokaiseen työntekijään, tarkentaa altistumistapahtuman ja kirjaa tarvittavat tiedot työterveyshuollon potilastietojärjestelmään ja tekee yhteistyötä työntekijän oman kotikunnan tartuntataudeista vastaavan lääkärin kanssa. Työterveyshuolto ohjaa työntekijää tekemään työturvallisuuden vaara- 
tapahtuma-ilmoituksen (HaiPro). Kyseessä on Työtapaturma ja vaaratyyppi on Tartuntavaara.

Selvitysprosessi on aikaa vievää sekä sen saavuttamat tulokset epävarmat, koska kontaktien kartoitus on muistinvaraista. Mikäli työyksikössä on joukkoaltistuminen ja/tai altistuminen koskee useita työyhteisön jäseniä, prosessi on edellä kuvattua vielä monimutkaisempi ja työläämpi.

\section{RFID-TEKNOLOGIAN HYÖDYNTÄMINEN}

Digitaalisen tiedon hyödyntäminen epidemiologisesta näkökulmasta on ollut ajankohtainen aihe koronapandemian aikana. Digitaalisen epidemiologian saralla on pandemian ymmärtämiseksi analysoitu tietoa erilaisista digitaalisista tietolähteistä, kuten älypuhelimista, terveysrekistereistä ja ympäristön seurantatiedoista (3). Sairaalaympäristössä erilaiset digitaaliset tietolähteet ovat rajattuja, sillä esimerkiksi henkilökohtaisen älypuhelimen kantaminen ei aina ole mahdollista työntekijöiden eikä potilaidenkaan kohdalla.

Radiotaajuuksilla toimiva etätunnistusteknologia (RFID) on jo vakiintunutta ja sitä hyödynnetään laajasti muun muassa kulunvalvonnassa, erilaisissa parkkiratkaisuissa ja toimitusketjujen hallinnassa (4). RFID-teknologiaa käytetään myös lisääntyvässä määrin terveydenhuollossa (5). Käyttöaiheina voivat olla esimerkiksi potilasturvallisuuden parantaminen, virheiden ehkäiseminen tai potilaiden odotusaikojen lyhentäminen (6).

Kuopion yliopistollisessa sairaalassa (KYS) ajanjaksolla elokuu 2020 - toukokuu 2021 toteutetun hankkeen avulla haettiin RFID -teknologiasta vaihtoehtoista mallia COVID -19 kontaktien jäljittämiseen. Hankkeella haettiin ratkaisua COVID -19 altistamien henkilökontaktien luotettavaan kartoittamiseen ja nopeaan jäljittämiseen henkilöstön keskuudessa. Sekä epäilty että varmistettu koronatautia sairastava henkilökunnan jäsen voi levittää koronavirusta ympäristöönsä. Hankkeen avulla tavoiteltiin uutta toimintamallia, jota voitaisiin hyödyntää tartuntaketjujen nopeaan, sujuvaan sekä luotettavaan selvittämiseen altistuneen henkilön hoitamien potilaiden sekä sairaalassa työskentelevien muiden henkilöiden suojaamiseksi. Tällaista toiminnallisuutta/toimintatapaa ei ole aikaisemmin selvitetty Suomessa eikä tietääksemme ole käytössä maassamme. Hanke kohdistui COVID-19 pandemian kansallisen strategian ”Testaa - jäljitä - eristä - hoida" kohtaan ”JÄLJITÄ". Hankeidean taustalla on COVID -19 pandemian synnyttämät vaatimukset suojata henkilökuntaa. Nykyinen toimintatapa on sellainen, että tartuntaketjujen tarkistaminen COVID -19 testin ollessa positiivinen tapahtuu tartuntataudeista vastaavien lääkäreiden sekä yksikön esihenkilöiden tai vastaavien hoitajien toimesta.

Hankkeelta odotettiin seuraavia tuloksia: 1) Jäljitysratkaisun saaminen pilottivaiheen jälkeen pandemian aikaiseksi pysyväksi ja oikeassa käytössä olevaksi ratkaisuksi KYSissä; 2) Mahdollisuus kohderyhmän laajentamiseen henkilökunnasta potilaisiin; 3) Jäljitysratkaisun hyödyntäminen myös muissa tartuntataudeissa.

Pitkäaikaisina tuloksina odotettiin lisäksi: 4) Epidemiaryppäiden hallinnan helpottumista ja altistumisten lukumäärän vähenemistä; 5) Jäljitysratkaisun laajentamista myös lääkintälaitteiden ja instrumenttien jäljitettävyyden kehittämiseen; 6) Mahdollisuutta jäljitysratkaisun käyttöönottoon myös muissa terveydenhuollon organisaatioissa.

Hankkeessa pilotoitiin toimintamallia, jonka tavoitteena oli RFID -teknologiaa hyödyntämällä nopeuttaa ja tarkentaa COVID -19-altistusten jäljittämistä työntekijöiden keskuudessa. Hankkeen toimenpiteinä vapaaehtoisille päivystysalueella työskenteleville henkilöille annettiin RFID-tunniste, jota he pitivät mukanaan työvuorojensa aikana. RFID-lukijoiden avulla kerättiin tietoa henkilöstön kontakteista ja niiden kestosta. Pilotin aikana ei jäljitetty oikeita altistumisia, vaan pilottivaiheen aikana kerättyjä tietoja käytettiin järjestelmän testaamiseen ja käyttökokemuksien hankkimiseen. RFID-tunnistejärjestelmällä ei ole integraatiota kolmansiin järjestelmiin, eli tunnistusratkaisu oli ns. Stand Alone. Kertyvä data oli eri tiloissa oleskeluaikaa, joka tallennettiin Googlen pilvipalveluun. Pilottivaiheessa ei kerätty minkäänlaisia henkilön tunnistetietoja. Lukutunnistus vaati sähkö- ja tietoliikenneliittymän (kaapelointi). Lukutunnistuslaite tunnisti henkilön saapumisen ja poistumisen, kun henkilö liikkui lukualueella.

Tammi-maaliskuussa 2021 toteutetussa pilotissa oli tarkoitus arvioida RFID-teknologian soveltuvuutta uuteen käyttötarkoitukseen, eli altistusten jäljittämiseen hoitohenkilöstön joukossa. RFID valittiin testattavaksi menetelmäksi, koska sen kanssa voi käyttää passiivisia ja kertakäyttöi- 
siä tunnisteita. Passiiviset tunnisteet ovat edullisia, eivätkä ne vaadi huoltoa tai paristoja. Näin ollen järjestelmä olisi tarpeen vaatiessa käyttöönotettavissa myös isoille kohderyhmille.

Pilotissa vapaaehtoiset henkilökunnan jäsenet $(\mathrm{n}=93)$ kantoivat työvuoroissa mukanaan RFID-tunnisteita, joiden liikkeistä päivystysalueelle asennetut RFID-lukijat tallensivat tietoa. Pilotissa ei jäljitetty oikeita altistumisia, vaan järjestelmään kertynyt tieto oli anonyymia ja kuvitellut altistumiset simuloitiin erilaisin skenaarioin. Kertyvän tiedon avulla tarkasteltiin muun muassa järjestelmän luotettavuutta sekä arvioitiin erilaisin hypoteesein korona-altistusten leviämistä.

\section{UUSIA MAHDOLLISUUKSIA JA HAASTEITA}

Kun oletetaan, että henkilöllä on todettu virustartunta, niin siitä hetkestä taaksepäin voidaan todentaa, missä tiloissa kyseinen henkilö on oleskellut esimerkiksi yli 15 minuuttia yhtäjaksoisesti ja mitkä muut tunnisteet ovat olleet samassa tilassa yhtä aikaa. Erilaisia rajaukseen käytettyjä parametreja on mahdollista muokata. Datan visualisointia ja sen mahdollisuuksia esiteltiin useammalla esimerkillä, joissa käsiteltiin tietoja yksittäisen tunnisteen tai tilarajauksen kautta.

Hankkeen tuloksena tavoiteltiin toimintamallia, jonka avulla pyritään vähentämään COVID -19-tartuntoja henkilöstön keskuudessa. Jos toimintamalli saadaan pysyvään käyttöön, altistuneen työntekijän altistumisen tarkistus nopeutuu ja työntekijä voidaan lähettää nopeasti kotiin pois työtehtävistä eikä hän ole enää tartuttamassa toisia työntekijöitä ja potilaita. Tällä hetkellä suojainten käyttö sekä rokotusten tuoma immuniteetti on vähentänyt huomattavasti karanteeniin asettamisen tarvetta, mutta koronatauti on edelleen arvaamaton - on raportoitu tapauksista, joissa kaksi rokoteannosta saanut henkilö on varoajan jälkeen sairastunut. Järjestelmän avulla olisi mahdollista tarkentaa ja nopeuttaa kontaktien jäljitystä.

Järjestelmästä olisi hyötyä sekä työntekijän että työnantajan kannalta, jos järjestelmän käyttäjät pystyttäisiin identifioimaan. Pilotissa ei nykylainsäädännön ja henkilötietojen käsittelyvaatimusten tuomien rajoitusten vuoksi ollut mahdollista testata RFID-tunnistamiseen perustuvaa toimintamallia oikeilla henkilöillä, ei alun perin suunnitellusti potilailla eikä työntekijöillä.
Tulosten perusteella näyttäisi siltä, että RFIDtunnisteen tulee sijoittua niin, että se olisi mahdollisimman vapaasti näkyvällä paikalla, jotta luennat onnistuisivat hyvin. Pilotti tuotti tärkeää tietoa, kun pohditaan minkälainen paikannusteknologia tulisi valita mihinkin käyttötilanteeseen. Hyvänä asiana pidettiin myös sitä, että käyttötapaustestit tehtiin käyttäjän näkökulmasta ja huomattiin, kuinka moni asia vaikuttaa luennan onnistumiseen. Pilotin aikana toteutetussa autenttisessa simulaatiossa hyödynnettiin käyttöympäristön ymmärrystä. Jäljitysratkaisu voidaan laajentaa lääkintälaitteiden ja instrumenttien jäljitettävyyden kehittämiseen. Hankkeesta saatavia välillisiä tuloksia hyödynnetään jatkossa KYSin paikannus- ja jäljityshankkeissa.

Järjestelmän luotettavuuteen liittyy kuitenkin useita huomioonotettavia ja kehitettäviä seikkoja. Järjestelmän lukijat ja niiden antennit vaativat paikan päällä suoritetun optimoinnin, jotta niiden lukutarkkuus olisi riittävä. Pilotissa huomattiin, että RFID-signaali ei kulje nesteen tai metallin läpi, mikä asettaa haasteita tunnisteen optimaaliselle sijoittelulle henkilöpaikannustarkoituksessa. RFID-lukijan laajasta lukualueesta huolimatta esimerkiksi taskussa pidetyn tunnisteen lukutarkkuus ei yltänyt toivotulle tasolle. Seuranta-alueen suunnittelu vaatiikin panostusta, jotta järjestelmä toimisi toivotulla tavalla muun muassa pitkien ja monitahoisten käytävätilojen kohdalla. Tärkeässä osassa on myös käyttöliittymä, jonka avulla kontaktit haetaan valtavan suuresta tietojoukosta.

Jäljitysratkaisun pilotin tulokset ovat lupaavia, mutta edellyttävät edelleen testaamista, huomioiden edellä kuvatut kehittämistarpeet, sekä kohderyhmän laajentamista. Käyttöönotto terveydenhuollon organisaatioissa edellyttää testaamista myös oikeilla henkilöillä. Tämä ei ole mahdollista ilman lainsäädännöllisiä muutoksia, etenkin henkilötietojen käsittelyn osalta. Jäljitysratkaisun laajentaminen COVID -19 -taudin ohella myös muihin tartuntatauteihin sisältää potentiaalin niin potilaiden, asiakkaiden kuin työntekijöiden turvallisuuden lisäämiseen. Maailmanlaajuisesti on arvioitu erilaisten tartuntatautien lisääntyvän (7, 8). Jos kohderyhmän laajentaminen ja järjestelmän käyttöönotto toteutuvat, altistuneiden henkilöiden jäljittäminen nopeutuu ja on luotettavampaa, epidemiaryppäiden hallinta helpottuu ja altistumisten lukumäärää pystytään pienentämään. 


\section{LÄHTEET}

1. Hellmich T.R., Clements CM, El-Sherif N, ym. Contact tracing with a real-time location system: A case study of increasing relative effectiveness in an emergency department. American Journal of Infection Control Volume 45, Issue 12, 1 December 2017, Pages 1308-1311. https://doi.org/10.1016/j.ajic.2017.08.014

2. Christodoulakis C, Asgarian A, Easterbrook S. Barriers to adoption of information technology in healthcare. CASCON '17: Proceedings of the 27th Annual International Conference on Computer Science and Software Engineering. November 2017 Pages 66-75. https://dl.acm.org/doi/10.5555/3172795.3172804

3. Tarkoma S, Alghnam S, Howell M.P. Fighting pandemics with digital epidemiology. EClinicalMedicine 2020: 26. https://doi. org/10.1016/j.eclinm.2020.100512 2589-5370

4. Landt, J. (2005). "The history of RFID" in IEEE potentials, vol. 24, no. 4, pp. 8-11, Oct.-Nov. 2005, https://doi.org/10.1109/MP.2005.1549751

5. Hu L, Ong DM, Thu W, ym. Enabling RFID technology for healthcare: application, architecture, and challenges. Telecommunications Systems Volume 58 Issue 3March 2015 pp 259271 https://doi.org/10.1007/s11235-014-9871-x

6. Lahtela, A. (2009, September). A short overview of the RFID technology in healthcare. In 2009 Fourth International Conference on Systems and Networks Communications (pp. 165-169). IEEE. https://doi.org/10.1109/ICSNC.2009.77

7. Sosiaali- ja terveysministeriön julkaisuja 2012:9. Kansallinen valmiussuunnitelma influenssapandemiaa varten. http://urn.fi/URN:ISBN:978-952-00-3347-7
8. WHO (2019) Global Preparedness Monitoring Board. A world at risk. Annual report on global preparedness for health emergencies. Geneva: World Health Organization; 2019. Licence: CC BY-NC-SA 3.0 IGO.

https://apps.who.int/gpmb/assets/annual_report/ GPMB_annualreport_2019.pdf

\section{Kaisa HaAtainen}

Potilasturvallisuuspäällikkö, FT, dosentti, Sosiaali- ja terveydenhuollon EMBA

Kuopion yliopistollinen sairaala, sairaanhoidon hallinto

Itä-Suomen yliopisto, Hoitotieteen laitos

\section{SONJA JULKUNEN}

Tutkimushoitaja, sh/YAMK

Kuopion yliopistollinen sairaala, tehohoidon osasto

ViIVi Kaskenaho

Apulaisosastonhoitaja, sh/YAMK

Kuopion yliopistollinen sairaala, päivystyspoliklinikka

\section{Marjo Kervinen}

Palvelukeskusjohtaja, LL, turvallisuusjobtamisen EMBA

Kuopion yliopistollinen sairaala, lääkinnällisten palvelujen hallinto 